\title{
SOCIAL WELFARE IN THE PUBLIC-PRIVATE STATE
}

\author{
Charles A. Reich *
}

A new philosophy of social welfare is struggling for recognition in this country. Today's public welfare programs still embody much of the old theory that welfare is a form of charity and that dependency is to be blamed on the individual. A more modern school of thought considers dependency a condition beyond the control of any individual, and seeks to establish the status of welfare benefits as rights, based upon the notion that every individual, in whatever circumstances, is entitled to share in the commonwealth.

The greatest obstacle to reforms in social welfare is the widely and stubbornly held belief that welfare is an anomaly in the American scene. This is a country where people are expected to take care of themselves, and the concept of social welfare, while generally accepted, is considered to be contrary to the natural order of things- to be discouraged if possible. The status of welfare as an anomaly is explicitly written into our laws. Welfare recipients are watched with suspicion; their use of welfare money is hedged by stringent limitations. These attitudes create a demand for frequent investigations to prevent "misuse" of benefits. In their zeal public agencies have claimed and exercised the privilege of entering recipients' homes at any hour of the day or night - the law literally pursues recipients into the bedroom. Supervision also appears in a prescriptive form: an insistence that the authorities have a right to concern themselves with recipients' family affairs and morality.

Welfare law is full of special burdens for those subject to its jurisdiction. Relatives' responsibility is one illustration-an attempt to impose on relatives duties of support not accepted in the rest of society. Federal poverty programs under the Office of Economic Opportunity have a special loyalty oath requirement-for the poor alone. And welfare recipients are regularly prosecuted for a special kind of crime-misuse of welfare funds-while others who receive public funds are generally not prosecuted criminally. Such invidious laws, and the general pattern of bureaucratic supervision, investigation,

* Professor of Law, Yale University. This article is based on a lecture given at the Graduate Department of Social Work and Social Research of Bryn Mawr College on the occasion of the Fiftieth Anniversary of the Department, October 23, 1965. 
and control, all conspire to increase dependency by preventing those who need welfare from leading normal lives or achieving independence and self-esteem.

This discriminatory pattern is justified on the theory that it is necessary to safeguard public funds. The legal argument is that government derives its special powers from the fact that its money is being used. Welfare income may be a family's chief source of support, but the money remains "public" in that the public concerns itself with how the welfare check is spent.

How can the status of social welfare be changed? If social welfare advocates insist upon trying to get the nation to accept a full blown welfare state philosophy, and at the same time expressly to abandon older ideals such as individual independence, they are assuming a difficult burden. These ideals are still cherished, and the welfare state still looks alien to many people. But social welfare reformers need not make such a frontal assault upon the American system. On the contrary, they may do better by seeking to fit welfare within present norms. Outside the welfare field, dependency on government is rapidly increasing in many areas of the economy. Today there is widespread private use of public funds. Many "independent" business lives are led with public assistance. This widespread and growing pattern of public-private cooperation furnishes a context which makes social welfare seem far less anomalous. Moreover, this cooperation has developed unique patterns which, if applied to social welfare, offer a route to many of the reforms which the new philosophy seeks to accomplish.

\section{I}

The public-private state has come unheralded-an unplanned, unacknowledged, and peculiarly American phenomenon. We have come to accept the idea of public subsidy of business when it is needed. The transportation industry is dependent on public assistance; airlines are subsidized on many short hauls; shipping is directly subsidized and indirectly aided by laws favoring the American flag; trucking is aided by public roads and protected from competition; rail transportation is beginning to receive aid. Second class mail rates are an essential subsidy for the magazine and periodical industry. Homeowners are given many types of financial guarantees and assistance. Farmers have been the beneficiaries of a public assistance program for many years. Many subsidies are less obvious or less well known but not less important. They include the supplying of facilities such as airports for the airline industry and docks for the shipping industry, resources such as hydroelectric sites for private power companies, the channels of the 
radio spectrum for radio and television, and the airways for the air transportation industry. Intellectual activity, especially scientific research, is also subsidized. Perhaps the biggest subsidies of all are some of our tax exemptions. Even the rancher, that paragon of independence, gets much help from the government. He may sit tall in the saddle as he rides off into the sunset, but the public domain on which he grazes his stock and the public water that fills his irrigation ditches are forms of government assistance. In short, a great many supposedly independent forms of economic activity are actually supported in accordance with need. In this sense at least, a good many of us are on the dole.

The emerging model of our society is that of a public-private partnership. The relationship is reciprocal. Government not only aids the private sector, but in addition many public functions are performed by private businesses and institutions. For example, the "Think Institutes" do research for government, and the defense industry engages in production for government-both functions which could be directly performed by government itself. There is a blurring of the line between "public" and "private," both in the political sense and in the legal sense. The public interest unavoidably extends to much of that which is nominally private.

The development of the public-private state is in line with the general trend of industrial societies. Whether their ideology is socialism or capitalism, most highly industrialized countries have followed a pattern of centralized planning and allocation of resources simply because the market is not able to function satisfactorily unassisted. But the American system of planning and allocation has developed with characteristics very different from anything found under socialism. Our system has from the beginning been shaped so as to maintain certain values that are regarded as peculiarly American. This shaping has perhaps not always been conscious, but a consistent pattern can be found.

Government payments to farmers offer an illustration. The payments are not presented as relief, but are pictured as restoring an imaginary balance in the economy, thrown out of kilter by large, anonymous forces depressing agricultural prices. In some instances the payments are made to appear as "transactions" in which the government has purchased commodities from the farmer. However, once payments pass into the hands of the farmer they cease to be treated as public funds and become "private"; the government is not concerned with what the farmer does with the money, nor does it attempt to supervise his private life. Thus in broad outline the pay- 
ments are designed in a fashion that tends to preserve the farmer's self-esteem and independence. The farmer need not feel that he is receiving public assistance like a welfare client.

Throughout the economy business subsidies follow this general pattern and include many other devices which maintain the illusion of free enterprise. The airlines are encouraged to "compete" although competition is made possible and maintained by governmental intervention. Ranchers make up local grazing committees that exercise substantial control over federally subsidized grazing privileges-a precursor, perhaps, of the idea that "the poor" should have a voice in the poverty program. Television licenses have elaborate procedural protection; a license cannot be revoked without due process hearings and an opportunity for court review.

If it is legitimate to derive a theory from a development that has been anything but conscious, it might be as follows. There is no avoiding the economic imperative of public-private cooperation, but the social (and legal) consequences are still subject to control. We could have virtually as much centralized regulation and private dependency as exists in a socialist country. But we have deliberately chosen to maintain, indeed, to construct, a maximum of individual sovereignty.

Whatever its validity in terms of political theory, the American public-private state seems to work. But because we have arrived at it without full awareness of what we were doing, and because to some extent at least it owes its success to the perpetuation of myths, there has been much opportunity for distortion and unfairness to become established. Primarily these distortions consist of inequities in the allocation of benefits. The greatest amounts of financial assistance have been won by those with the greatest political power. Thus, there is much more aid for home ownership than for public housing, much more assistance for agriculture than for the urban worker (the structure of federal tax exemptions and rates is one of the most telling reflections of the relative strengths of various interests). In addition there is the problem of control over the recipients. A public-private economy necessarily leaves great power in private hands, and this power can and is frequently used to influence government, so that more powerful recipients manage to direct the allocation as well as benefit from it. This leads to a further distortion. The rules are different for some forms of assistance than for others, because some people make the rules for themselves and others live under rules made for them. The American experiment in allocation carries great danger of injustice along with its efforts to preserve our older traditions. 
The development of the public-private state has many important implications. It presents a general problem of the dangers of centralized governmental power in a country established under principles of strictly limited powers. It raises questions concerning standards of fairness and equal treatment when the day comes that governmental assistance to various areas of the economy is the rule and not the exception. It suggests that private corporations and institutions, to the extent they use public money and exercise what are in effect delegated governmental powers, may properly be subject to the constitutional Bill of Rights when they deal with individuals such as employees or students. And it implies that these same private organizations must be subject to some forms of democratic control, internal or external, that are more effective than public regulation or "stockholder democracy" have proven to be.

These broad issues must be left to another day. But they touch, to some degree at least, on a further question raised by the arrival of the public-private state: the place of social welfare. Let us now return to this problem.

\section{II}

If the above description of the pattern of the American economy has been accurate, it may be seen that dependency and social welfare are not an anomaly but part of a much more general development in this country. But the public-private state has a double standard-one for aid to business and the farmer, and a very different one for welfare. It is a double standard from the moral point of view and a double standard from the legal point of view. There is a law for the poor and a law for the rest of us. Receipt of government aid by the poor has carried a stigma whereas receipt of government aid by the rest of the economy has almost been made into a virtue. Indeed one can detect a strong element of self-righteousness in the fact that some of those who receive public assistance, like ranchers, are quick to assume an attitude of condemnation toward those who need that other form of assistance called social welfare. The effect of this double standard is to deny to welfare recipients the values and protections that the rest of the publicly supported private economy enjoys, and to do so on high moral grounds. Social welfare is thus left out of the developing American public-private state. This may serve to perpetuate the myths and perhaps the power of the private economy, but it is hard on the people who most need help.

This double standard may properly be made the rallying point for social welfare reform. There is no need for social welfare to 
struggle against the current of American society. Welfare's philosophers may simply ask that the urban poor be treated according to the model already established for farmers and businessmen. If welfare, like the rest of the American assistance program, were designed to enhance such values as independence and self-esteem, many of the current goals of welfare reform would be achieved.

To what extent are the value preserving devices of the publicprivate state usable in the welfare field? In theory at least, many should be. To begin with, the right to receive welfare could be based on objective statutory criteria, giving a maximum of certainty and security to recipients. The right to a second class mail subsidy is based upon a precise statutory formula which leaves the Post Office Department virtually no discretion. In welfare, objective entitlement would be the foundation of family independence and security; it would serve a far more important function than in the case of periodicals. It is quite true that the idea of entitlement implies a less suspicious and grudging attitude toward recipients' need. But we have not forced each farmer or each homeowner to prove his need, and we have not gone bankrupt in consequence. Indeed we have learned to accept the sight of a well to do farmer who is getting government assistance-a reality that is far less disturbing than the unlikely fantasy of wealthy welfare clients spending their government checks at resort hotels.

Second, the receipt of welfare should not be the occasion for any special excesses of governmental regulation and invasion of privacy. Government has ample power to prevent neglect of children, unsanitary living conditions, or other ills which may occur in families whether or not they are receiving public assistance. The welfare recipient should not be a second class citizen whose home is open to invasion and whose morals are subject to scrutiny by reason of his acceptance of public benefits. That is not to say that social work, medical care and psychiatric help should not be available to those who need it. The point is simply that there is no necessary link between acceptance of benefits and governmental supervision.

A third objective for social welfare should be the institution of procedural safeguards comparable to those long established in connection with many other types of public benefits. A television license can be revoked only after the most scrupulous observance of due process hearing and review procedure. But people can be cut off from welfare, or put out of a public housing project in far more summary fashion. Procedural safeguards are the norm, not the exception, in our society. It should be as hard to evict a public housing tenant as any other 
tenant. The development of procedural safeguards in the welfare field has lagged because up to now few lawyers have been enlisted to represent welfare clients. As every lawyer knows, procedure is the first line of defense against governmental arbitrariness.

Finally, welfare needs some of the devices that give others who receive public benefits a sense of dignity and participation in the work of society. In the case of farmers the two primary devices were the "transaction" method of payment plus a measure of local self government through committees. Neither device is readily applicable to the welfare field, but with some imagination substitutes might be provided. After all, the New Deal experimented with offering opportunities for creative work (as opposed to punitive types of work) to those on relief. And the poverty program is now experimenting with local democracy and participation. These values can surely be introduced into social welfare as well. Through such methods, the stigma of dependency might ultimately be eradicated.

With respect to each of the four proposals that have been mentioned, law is the best available instrument for achieving the necessary changes. All too often, law is used as an excuse for maintaining an unjust status quo. It has been cited in just this way to obstruct reform in social welfare, by insisting that certain forms of regulation are necessary consequences of the furnishing of welfare benefits. But no form of law is ever necessary or inevitable. Law is the servant of social policy, not a determinant of it. It is our policy that must change.

In 1966 the uniqueness of America is no longer found in an economic system. Our system and those of socialist countries are growing more alike every day. The uniqueness of our country lies in its insistence on maintaining values like privacy and individual dignity regardless of the economic system. That is the hope of the publicprivate state. When we degrade welfare recipients, we are eroding the very values we seek to preserve. But it is not merely enlightened self interest, but justice, that demands a new design for social welfare. In the public-private state we have worked out a model for our society; while that experiment prevails, welfare recipients are entitled to be a part of it. They are entitled to share in the values, the hopes and the work of America. 